\title{
The erythrocyte cytoskeleton protein 4.2 is not demonstrable in several mammalian species
}

E.M. Guerra-Shinohara ${ }^{1}$ and O.C. de O. Barretto ${ }^{2}$

\section{Correspondence \\ E.M. Guerra-Shinohara \\ Av. Dr. Arnaldo, 355 \\ 01246-092 São Paulo, SP \\ Brasil \\ Fax: +55-11-853-3505}

Presented at the XIII Annual Meeting of the Federação de Sociedades de Biologia Experimental, Caxambu, MG, Brasil, August 26-29, 1998.

Research supported by CN Pq Publication supported by FAPESP.

Part of a doctoral thesis presented by E.M. Guerra-Shinohara to the Departamento de Análises Clínicas e Toxicológicas, Faculdade de Ciências Farmacêuticas da Universidade de São Paulo.

Received April 14, 1998 Accepted March 1, 1999

\author{
${ }^{1}$ Seção de Hematologia, Divisão de Patologia, Instituto Adolfo Lutz, \\ São Paulo, SP, Brasil \\ ${ }^{2}$ LIM-23 and LIM-27, Departamento de Psiquiatria, Faculdade de Medicina, \\ Universidade de São Paulo, São Paulo, SP, Brasil
}

\begin{abstract}
Erythrocyte membrane proteins from 44 representative mammals were studied. Protein 4.2 was not detected in guinea pigs (Cavia porcellus) $(\mathrm{N}=14)$, Southern Brazilian swamp large rats (Myocastor coypus) $(\mathrm{N}=2)$, cutias (Dasyprocta $\mathrm{sp})(\mathrm{N}=4)$, and horses (Equus caballus $)(\mathrm{N}=13)$. These animals also presented high ankyrin concentrations except for the horse which did not exhibit a sharp band, although minor components located between proteins 2 and 3 could account for the ankyrin family. The rodents studied did present band 6 , which was not detectable in other common rodents such as white rats (Rattus norvegicus) $(\mathrm{N}=9)$ and mice (Mus musculus) $(\mathrm{N}=12)$. Since the absence of protein 4.2 does not disrupt the cytoskeleton membrane, we suggest that it is not an essential protein. Its absence may be compensated physiologically by the higher ankyrin concentration observed.
\end{abstract}

\section{Key words \\ - Protein 4.2 \\ - Erythrocyte membrane cytoskeleton \\ - Mammals}

Human erythrocyte membrane proteins have been extensively studied, and band 3 and glycophorins have been classified as integral proteins, and the spectrins, band 2.1, band 4.1 , band 4.2 , band 4.5 , band 4.9 , band 5 (actin), band 6 (glyceraldehyde-3-phosphate dehydrogenase), and band 7 as peripheral proteins. The peripheral proteins which form the cytoskeleton are very important for maintaining the protein network just below the membrane lipid bilayer (1). In general, mammals present small variations in erythrocyte membrane protein concentration as well as in molecular weight (2). Variable spectrin and ankyrin concentrations have been reported in mice (3-8), as well as a molecular weight variation of band 3 in non-human primates (9), its enrichment in llamas (10), and the absence of band 6 in rats and mice $(11,12)$.

In the course of an extensive investigation of red cell membrane proteins (2), 44 selected representatives of mammalian species belonging to 13 orders from Brazilian Zoos and Brazilian Research Institutes were investigated (Table 1). Red cells were collected into acid-citrate-dextrose solution, washed in buffered saline and lysed in cold 5 
Table 1 - Mammals whose erythrocyte membrane proteins were studied and their relative amount of protein 4.2 .

*The densitometer was not able to discriminate between band 4.1 and band 4.2 , although both bands could be observed visually.

\begin{tabular}{|c|c|c|c|c|}
\hline Scientific name & $\mathrm{N}$ & Family & Order & band 4.2 percent (SD) \\
\hline Homo sapiens & 20 & Hominidae & Primates & $7.5(1.7)$ \\
\hline Cebus apella & 15 & Cebidae & Primates & $9.4(1.5)$ \\
\hline Alouatta sp & 6 & Cebidae & Primates & $8.0(2.2)$ \\
\hline Ateles paniscus chamek & 4 & Cebidae & Primates & $6.5(1.2)$ \\
\hline Gorilla gorilla & 1 & Pongidae & Primates & 7.1 \\
\hline Pongo pygmaeus & 2 & Pongidae & Primates & $5.4(1.0)$ \\
\hline Erythrocebus pata & 2 & Cercopithecidae & Primates & $9.5(1.2)$ \\
\hline Papio cynocephalus & 1 & Cercopithecidae & Primates & 5.9 \\
\hline Arctocephalus tropicalis & 2 & Otariidae & Pinnipedia & $7.7(0.7)$ \\
\hline Arctocephalus australis & 1 & Otariidae & Pinnipedia & 7.2 \\
\hline Acinonyx jubatus & 1 & Felidae & Carnivora & 5.8 \\
\hline Felis concolor & 1 & Felidae & Carnivora & 7.3 \\
\hline Panthera onca & 3 & Felidae & Carnivora & $8.9(1.0)$ \\
\hline Panthera leo & 6 & Felidae & Carnivora & $8.9(1.8)$ \\
\hline Panthera tigris & 2 & Felidae & Carnivora & $8.0(2.2)$ \\
\hline Panthera pardus & 2 & Felidae & Carnivora & $7.0(1.5)$ \\
\hline Procyon cancrivorus & 1 & Procyonidae & Carnivora & 4.3 \\
\hline Nasua nasua & 6 & Procyonidae & Carnivora & $8.1(0.6)$ \\
\hline Chrysocyon brachyurus & 6 & Canidae & Carnivora & $6.7(0.4)$ \\
\hline Cerdocyon thous & 6 & Canidae & Carnivora & $8.6(1.8)$ \\
\hline Canis familiaris & 13 & Canidae & Carnivora & $7.0(1.3)$ \\
\hline Cavia porcellus & 14 & Caviidae & Rodentia & 0 \\
\hline Rattus novergicus & 9 & Muridae & Rodentia & $10.2 *(0.6)$ \\
\hline Mus musculus & 12 & Muridae & Rodentia & $5.9(1.3)$ \\
\hline Myocastor coypus & 2 & Myocastoridae & Rodentia & 0 \\
\hline Dasyprocta sp & 4 & Dasyproctidae & Rodentia & 0 \\
\hline Mesocricetus auratus & 8 & Cricetidae & Rodentia & $12.9 *(0.9)$ \\
\hline Oryctolagus cuniculus & 15 & Leporidae & Lagomorpha & $7.4^{*}(1.2)$ \\
\hline Bradypus tridactylus & 2 & Bradypodidae & Edentata & $10.2 *(0.9)$ \\
\hline Elephas maximus & 1 & Elephantidae & Proboscidea & 5.1 \\
\hline Camelus bactrianus & 3 & Camelidae & Artiodactyla & $6.3(0.9)$ \\
\hline Giraffa camelopardalis & 1 & Giraffidae & Artiodactyla & 5.2 \\
\hline Cervus elaphus & 2 & Cenvidae & Artiodactyla & $6.0(0.7)$ \\
\hline Ozotoceros bezoarticus & 1 & Cenvidae & Artiodactyla & 5.7 \\
\hline Mazama gouazoubira & 3 & Cenvidae & Artiodactyla & $7.5(1.4)$ \\
\hline Ovis aries & 15 & Bovidae & Artiodactyla & $5.4(1.1)$ \\
\hline Bos taurus & 6 & Bovidae & Artiodactyla & $10.1 *(1.1)$ \\
\hline Bos indicus & 15 & Bovidae & Artiodactyla & $10.6 *(1.9)$ \\
\hline Capra hircus & 19 & Bovidae & Artiodactyla & $3.2(0.2)$ \\
\hline Tapirus terrestres & 1 & Tapiridae & Perissodactyla & $12.3^{*}$ \\
\hline Equus callus & 13 & Equidae & Perissodactyla & 0 \\
\hline Inia geoffrensis & 6 & Iniidae & Cetacea & $10.9 *(0.9)$ \\
\hline Tadarida brasiliensis & 1 & Molossidae & Chiroptera & $9.5^{*}$ \\
\hline Trichechus inunguis & 4 & Trichechidae & Sirenia & $11.1(1.7)$ \\
\hline Didelphis marsupialis & 8 & Didelphidae & Didelphimorphia & $8.8(1.7)$ \\
\hline
\end{tabular}


mM sodium phosphate buffer, $\mathrm{pH} 8.0$, containing the following protease inhibitors: 0.2 $\mathrm{mM}$ phenylmethylsulfonyl fluoride, $0.2 \mathrm{mM}$ $\mathrm{N}$-ethylmaleimide, $1.0 \mathrm{mM}$ disodium ethylenediaminetetraacetate, $0.1 \mathrm{mM}$ diisopropylfluorophosphate, $0.1 \mathrm{mM}$ Na-p-Tosyl-Llysine chloromethyl ketone, $0.1 \mathrm{mM} p$-hydroxymercuribenzoic acid, and $1 \mu \mathrm{M}$ pepstatin A.

The ghosts were washed with the same buffer, solubilized by standard methods and submitted to SDS-polyacrylamide gel electrophoresis (SDS-PAGE), using 10\% polyacrylamide gel (13) as well as an exponential gradient (3-17\%, with piston) polyacrylamide gel (14). A ghost sample without protease inhibitors was also prepared.

Coomassie Blue $(0.605 \mathrm{mM})$ in isopropanol:acetic acid:water $(5: 2: 6)$ was used to stain the SDS gels. An Ultrascan XL laser densitometer (Pharmacia) was used with gelscan/92 software. Figure 1 illustrates the SDS-PAGE of the erythrocyte proteins from the animals which did not present protein 4.2 and shows that the patterns were constant in the presence of individual inhibitors and the pool of all inhibitors.

The red cell morphology of all animals lacking band 4.2 is shown in Figure 2. In comparison with human red cells, it can be seen that Equus caballus erythrocytes are microcytic and that Rodentia erythrocytes are similar to human except for those of Dasyprocta sp, which exhibit occasional stomatocytes. However, it is difficult to ascribe these morphological differences to the absence of protein 4.2.

The following Rodentia representatives did not contain demonstrable protein 4.2: guinea pig (Cavia porcellus) $(\mathrm{N}=14)$, Southern Brazilian swamp large rats (Myocastor coypus) $(\mathrm{N}=2)$, and cutias (Dasyprocta $\mathrm{sp})$ $(\mathrm{N}=4)$. Horses (Equus caballus) $(\mathrm{N}=13)$ also did not exhibit protein 4.2. These animals also presented high ankyrin concentrations except for horses, which did not exhibit a sharp band although they showed a group
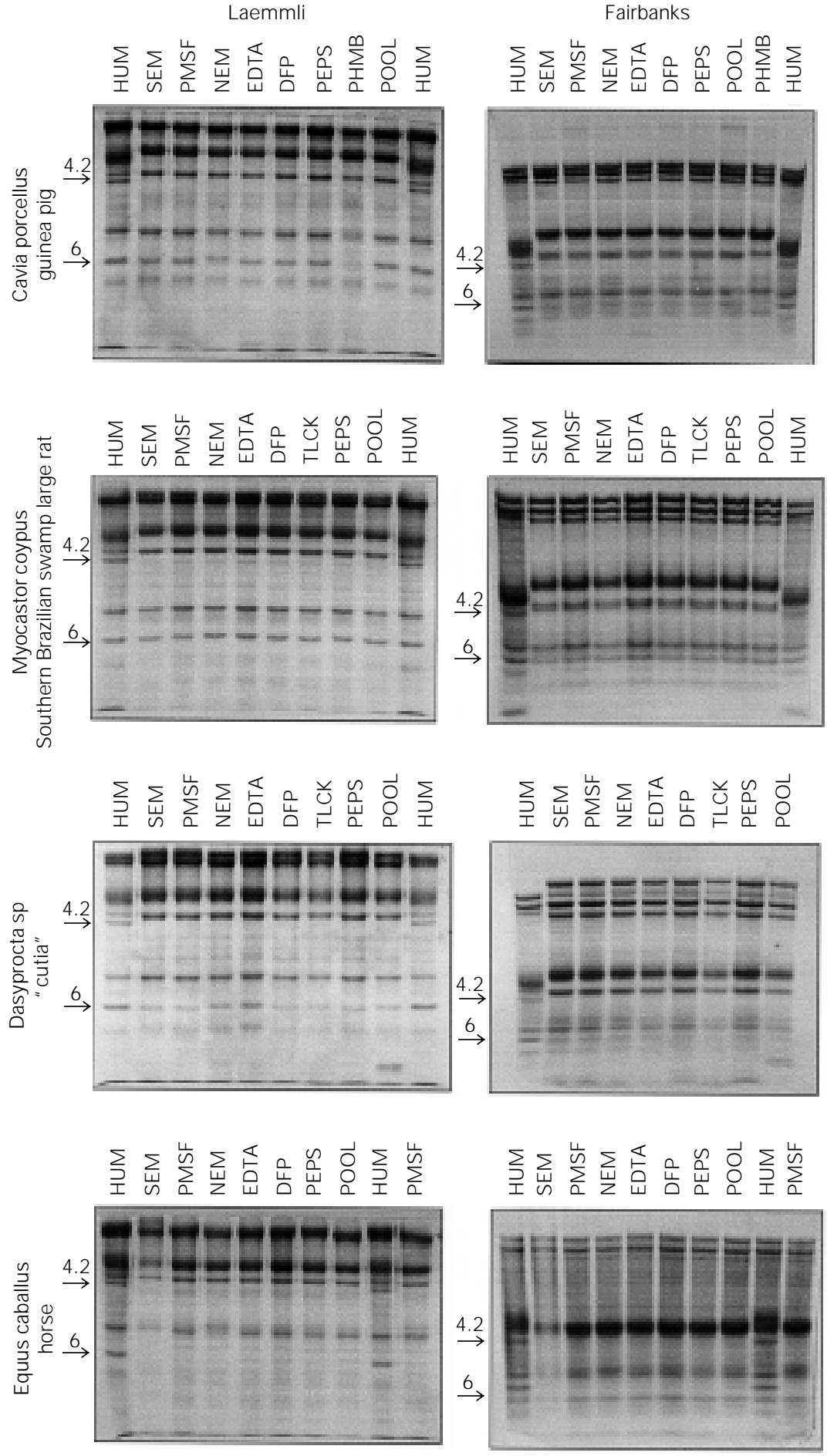

Figure 1 - Absence of erythrocyte membrane protein 4.2 in Cavia porcellus, Myocastor coypus, Dasyprocta sp and Equus caballus in SDS-PAGE. HUM, Human erythrocyte membrane protein; SEM, without any inhibitor; PMSF, phenylmethylsulfonyl fluoride; NEM, Nethylmaleimide; EDTA, disodium ethylenediaminetetraacetate; DFP, diisopropylfluorophosphate; PEPS, pepstatin A (isovaleryl-VaL-VaL--Sta-Ala-Sta); PHMB, p-hydroxymercuribenzoic acid; POOL, mixture of all inhibitors; TLCK, Na-p-Tosyl-L-lysine chloromethyl ketone. 
Figure 2 - Red cell morphology of animals lacking protein 4.2. Human erythrocytes are used as a comparative sample. Magnification: 1000X. of minor components located between proteins 2 and 3, which could account for an ankyrin family. Protein 4.2 has been considered to play an important role in cytoskeleton anchorage to the integral protein 3, together with ankyrin (band 2.1).

Inaba and Maede (15) reported the finding of a putative membrane protein 4.2 between $4.1 \mathrm{a}$ and $4.1 \mathrm{~b}$ of horse erythrocyte membrane. This, however, was not observed in our study. Bands 4.1a and 4.1b always remain together, and the hypothesis raised by these investigators of an undefined band between $4.1 \mathrm{a}$ and $4.1 \mathrm{~b}$ may be due to an

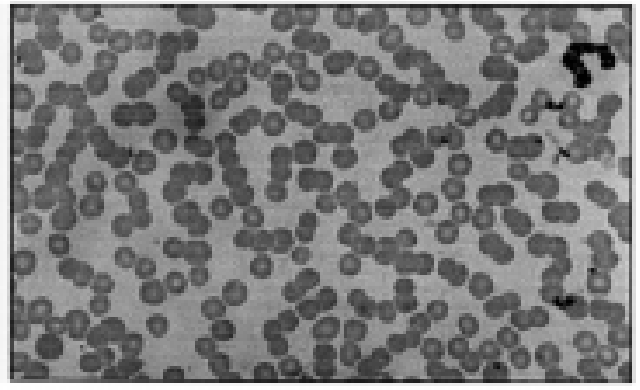

Equus caballus horse

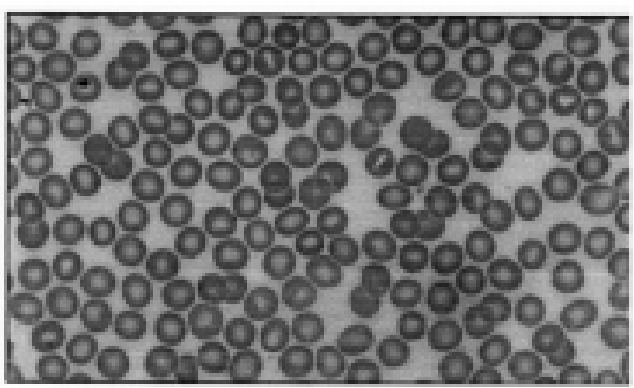

Dasyprocta sp

"cutia"

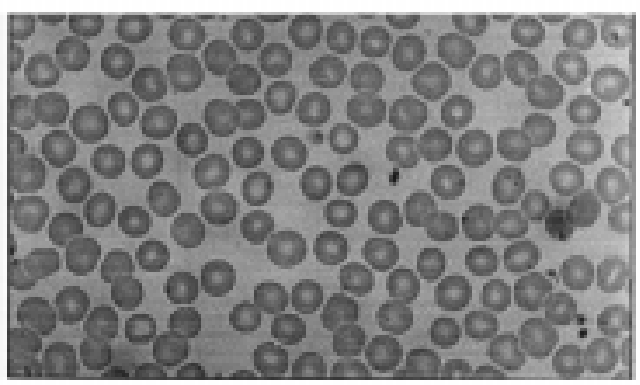

Homo sapiens

man artifact since an antibody against 4.2 was not employed in their study. If a band 4.2 exists in horse erythrocytes, it should be detected as a protein of lower molecular weight than proteins $4.1 \mathrm{a}$ and $4.1 \mathrm{~b}$.

The rodent species studied here did present band 6, which does not occur in other common Rodentia $(11,12)$ such as white rats (Rattus norvegicus) $(\mathrm{N}=9)$ and mice (Mus musculus) $(\mathrm{N}=12)$ (see Figure 1).

Protease inhibitors were employed in order to exclude the possibility that the absence of band 4.2 was due to proteolysis. However, since antibodies to band 4.2 were

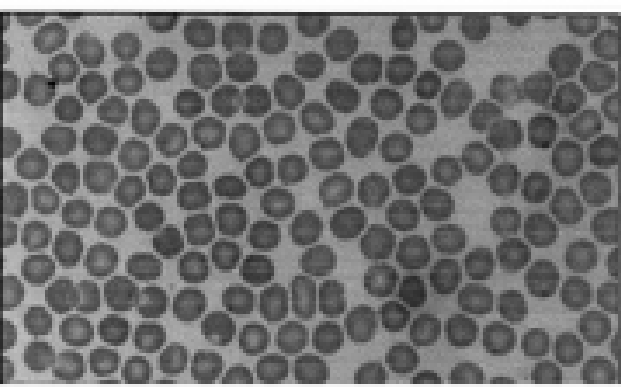

Cavia porcellus guinea pig

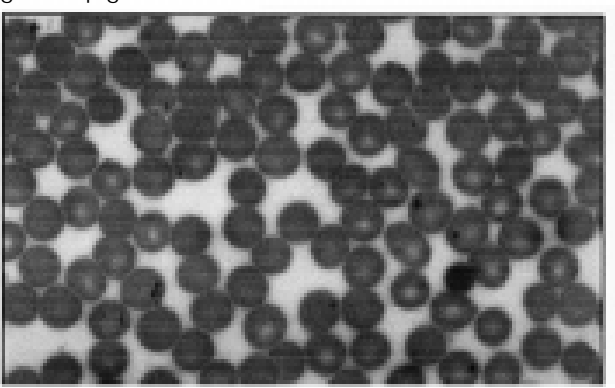

Myocastor coypus

Southern Brazilian swamp large rat 
not used in the present study, the possibility of a band immunologically similar to the protein of band 4.2 but of different molecular weight cannot be ruled out.

Our data, however, do suggest that protein 4.2 is not an essential protein since its absence does not disrupt the cytoskeleton membrane. Physiologically its absence may be compensated for by the higher ankyrin concentration observed in the mammals lacking band 4.2 .

\section{References}

1. PalekJ (1995). The red cell membrane. In: Beutler E, Lichtman MA, Coller BS \& Kipps TJ (Editors), Williams Hematology. 5th edn. McGraw-Hill, New York, 536-563.

2. Guerra-Shinohara EM (1996). Estudo das proteínas de membrana eritrocitária de mamíferos de treze ordens da Classe Mammalia. Doctoral thesis, Faculdade de Ciências Farmacêuticas da Universidade de São Paulo, São Paulo.

3. Greenquist AC \& Shohet SB (1978). Marked reduction of spectrin in hereditary spherocytosis in the common house mouse. Blood, 51: 1149-1155.

4. Whitfield CF, Mylin LM \& Goodman SR (1983). Species-dependent variations in erythrocyte membrane skeletal proteins. Blood, 61: 500-506.

5. Brookoff D, Maggio-Price L, Bernstein $S$ \& Weiss L (1982). Erythropoiesis in ha/ha and sph/sph mice, mutants which produce spectrin-deficient erythrocytes. Blood, 59: 646-651.

6. Reinhart $W H$, Sung LPA, Sung PKL,
Bernestein SE \& Chien S (1988). Impaired echinocytic transformation of ankyrin and spectrin-deficient erythrocytes in mice. American J ournal of Hematology, 29: 195200.

7. Bernestein SE (1980). Inherited hemolytic disease in mice: a review and update. Laboratory Animal Science, 30: 197-205.

8. Bodine IV DM, Birkenmeier CS \& Barker JE (1984). Spectrin deficient inherited hemolytic anemias in the mouse: characterization by spectrin synthesis and mRNA activity in reticulocytes. Cell, 37: 721-729.

9. Palatnik M, Simões MLMS, Alves ZMS \& Laranjeira NSM (1990). The 60 and 63 $\mathrm{kDa}$ proteolytic peptides of red cell membrane band- 3 protein $=$ their prevalence in human and non-human primates. Human Genetics, 86: 126-130.

10. Khodadad J K \& Weintein RS (1983). The band 3-rich membrane of llama erythrocytes: studies on cell shape and the organization of membrane proteins. J ournal of Membrane Biology, 72: 161-171.
11. Ballas SK, Kliman HJ \& Smith ED (1985). Glyceraldehyde-3-phosphate dehydrogenase of rat erythrocytes has no membrane component. Biochimica et Biophysica Acta, 831: 142-149.

12. Ballas SK (1987). Comparative distribution of glyceraldehyde-3-phosphate dehydrogenase activity in human, guinea-pig, rabbit, and mouse erythrocytes. Comparative Biochemistry and Physiology, 87B: 837-842.

13. Laemmli UK (1970). Cleavage of structural proteins during the assembly of head of bacteriophage T4. Nature, 227: 680685.

14. Fairbanks G, Steck TL \& Wallach DFH (1971). Electrophoretic analysis of the major polypeptides of the human erythrocyte membrane. Biochemistry, 10: 26062617.

15. Inaba M \& Maede $Y$ (1988). Correlation between protein $4.1 \mathrm{a} / 4.1 \mathrm{~b}$ ratio and erythrocyte life span. Biochimica et Biophysica Acta, 944: 256-264. 